\title{
The Culture Content in Listening Material to Improve Foreign Students' Understanding of Indonesian Language
}

\author{
Laily Nurlina ${ }^{1}$ and Andayani ${ }^{2}$ \\ \{lailynurlina@ump.ac.id ${ }^{1}$, andayani@staff.uns.ac.id ${ }^{2}$ \} \\ ${ }^{1}$ Universitas Muhammadiyah Purwokerto, Indonesia \\ ${ }^{2}$ Universitas Sebelas Maret, Surakarta, Indonesia
}

\begin{abstract}
Most foreign students come to study in Indonesia without prior knowledge of the Indonesian language. As a result of this, we have developed listening materials to facilitate their ability to learn the language. However, the effectiveness of the listening material in increasing communicative skill and cultural understanding has not been proved. The data obtained at the exploratory stage, were obtained from a documentary study, class observation, FGD (Focus Group Discussion)and questionnaire. A descriptive-qualitative approach was used to evaluate the extracted data, which was experimentally tested. The findings indicated the following: (1) the listening material was not up to standards, (2) it lacked cultural understanding, and (3) there is a need for listening materials containing local culture. The listening material prototype was used in three Indonesian classes at different universities and regions. Some of the foreign students were from Thailand, Korean, Hungarian, Lithuania, and Sudan. The listening was analyzed using the one way-ANOVA using a reliability test of $0.404,0.121$ normality test, and 0.525 homogeneity tests. Based on ANOVA, $\mathrm{F}$ calculation was 1.482 while $\mathrm{F}$ table was 0.24 at the significant level $=0.05$. Therefore, it can be concluded that using the listening material containing local culture is more effective than the previous one.
\end{abstract}

Keywords: culture, listening material, foreign students, communicative skill, material development

\section{INTRODUCTION}

Teaching Indonesian as a second language is urgently needed. One of the problems in the teaching of Indonesian language is standardized materials. The Indonesian Teaching for Foreign Students Institution (ITFSI) used learning materials adapted based on their need. Foreign students generally study using three ways ${ }_{2}$ ) Indonesian as a communicative tool, 2) art and culture to know Indonesian habits $s_{2}$ and 3) socio-culture to understand the community. Three of them can be taught in the teaching of Indonesian language as a second language, particularly by introducing local culture [1]. Therefore, it is interesting to integrate Javanese culture into learning materials. 
Education often neglects the importance of local culture, local knowledge ${ }_{2}$ and local wisdom. Learning language also means learning its culture [2]. Foreign students can survive in a new environment by learning not only a new language but also a new culture [3]. The effort to connect culture and language learning comes from sociolinguistics theory. From a linguistics point of view, the competence to use a language depends not only on grammar mastery but also the ability to speak.

Many foreign students experienced cultural shock when firstly coming to Indonesia [4]. They could not speak Indonesian fluently and experienced difficulties in adapting to the community, food, weather, daily habits, and so on. Indonesian policy gives a different treatment in relation to the duty of mastering language for foreign students. Other countries force Indonesian people to achieve a particular IELTS score or TOEFL before they study in the countries. The students and teachers must open their minds because cultures in the world are various. Contextual materials help students connect to daily life ${ }^{5}$. Learning material is the most important component. The culture of Java is chosen because of its unique value and different characteristics, such as the culture of Banyumas, Solo, and coastal area.

One of audiovisual technologies is video as a communicative channel for delivering messages related to visual (video) and audio (voice). The development of audiovisual materials is needed because the materials can help foreigners to understand how to communicate in life. By having audio-visual materials, students can quickly understand Indonesian language. Some advantages of video are visualizing movement, relationships, and the resulting effect of materials. Foreign students can play the videos, study autonomously, and observe the mouth movement by watching the videos. This listening material includes audio files for listening practices, audio-visual with local culture dialogues to introduce the culture, and handbooks for teachers and learners.

\section{RESULT AND DISCUSSION}

A study by Andayani investigated the effectiveness of Indonesian textbooks containing local culture for foreigners who had English proficiency backgrounds and groups that could not speak English [6]. The results of this study indicate that textbooks integrated with local culture enhances the students' understandings of culture and communication skills. The difference with the research that will be developed is that while Andayani used four language skills tested in two Indonesian learning groups, this study develops teaching materials for listening skills containing Javanese culture.In line with Andayani's study, only a few learners experienced difficulties in comprehending the listening text due to the fact that the content wasrelated to their prior knowledge [7]. It means that learners need more information about Indonesian culture before they communicate with people. Some adults (foreigners in this case) used $45 \%$ of their time for listening, $30 \%$ for speaking, $16 \%$ for reading, and only $9 \%$ for writing. This shows that listening and speaking are very important for our daily life [8]. Listening is a basic skill close to understanding but less in critical thinking [9]. Listening needs special learning materials related to authentic criteria, not only repeating materials.

Learning material is the most substantial component and can be observed because it can measure language quality and language practice during learning in a classroom. Contextual material helps students connect to daily life. A proper approach to understanding the Indonesian syntax is the contextual approach 10]. Local culture value is a special element related to the community way of life as a national identity and can be implemented in any situation. Language is not a culture-free code, distinct from the way people think and behave, but it plays a big role in culture, particularly in printed form [11]. The intent is to enrich 
Indonesians' understanding about culture ${ }_{2}$ not only foreigners but also readers and users of this material. After finishing the study, the students spoke fluently and understood the culture well.

This research started with a needs analysis of listening materials enriched with Javanese culture to boost communicative skill and cultural understanding for foreigners. In developing the materials, the researcher considers three aspects: (1) developing a model, (2) developing procedures consisting of an exploration study, design and development, and (3) data, instrument, subject, and research data analyzes [12].

\subsection{Preliminary Stage}

Based on the research at the preliminary stage, it was found that the Indonesianteaching materials used in UniversitasMuhammadiyahPurwokerto (UMP), UniversitasSebelasMaret (UNS), and UniversitasNegeri Semarang (UNNES) still separate communication materials and cultural materials. The findings at this stage indicated that (a) some ITFSI do not have their own teaching materials; (b) learning materials are taken from modified reference books and internet so that learners can learn local culture; (c) Some ITFSI have not developed materials so they use various sources of books tailored to the needs of foreign students. Teachers must always make worksheets or material sheets at each meeting to support Indonesian language learning; (d) there are some foreign students who do not like learning culture so that the teacher does not prepare local cultural materials; (e) the books used are not in accordance with the Indonesian Curriculum for Foreign Students from Balai Bahasa; (f) teaching books are made by foreign speakers; $(\mathrm{g})$ textbooks made by foreign speakers tend to compare Indonesian culture and the culture of the writer; and (h) many instructors take advantage of outside-class activities to introduce the culture of the region.

\subsection{Needs Analysis}

The results of the needs analysis were as follows (a) listening teaching materials are needed at ITFSI; (b) the need for listening teaching materials containing Central Java local culture in the form of theory and practice can be realized in books and videos; (c) Indonesian books need to be developed with the content of the local culture of Central Java; (d) Indonesian teaching textbooks are equipped with syllabi and methods of teaching Indonesian for foreign speakers so that it is easier for teachers; (e) Indonesian learning is where listening is carried out more communicatively with teaching materials equipped with audio listening and video; (f) the importance of teaching materials are loaded with local culture so that foreign students do not need to learn twice, they do not need to study in two different classes namely language class and cultural class; $(\mathrm{g})$ cultural knowledge is very important especially with regard to communication and social methods information with the surrounding community; and (h) culturally charged teaching materials are needed to bridge communication and listening-based learning materials. These eight results are in line with the research of Hermayati indicating that teaching materials with cultural values will assist learners in understanding [13].

\subsection{Development Stages}

The process of developing teaching materials has several stages: requesting teacher inputs through a Focus Group Discussion (FGD), requesting input from Indonesian experts, limited trials, and more extensive trials. These four things are implemented because the developed teaching materials have to be able to meet the needs of foreign students and their teachers for improving their ability to listen. 
FGD processes include: first, designing a syllabus of listening and speaking learning with local culture for foreign students in Central Java; second, developing competency standards based on competency standards made by Badan Bahasa with some adjustments; third, describing the eight competency standards into a number of basic competencies listening and speaking according to the context of the environment and local culture; fourth, designing four different and varied methods of Indonesian learning at each meeting adjusted to the themes of lectures, discussions, brainstorming, and role playing; the fifth step of the FGD is to arrange the material framework tailored to the standards of competence and basic competencies and to rank the themes; and sixth, developing a material framework into teaching materials that are in accordance with the needs analysis in the exploration phase.

The second process of developing teaching materials is asking for an assessment from two experts: Dr. Ari Kusmiatun from UniversitasNegeri Yogyakarta and WatiIstanti, M.Pd. from UNNES. The inputs given include (a) Middle level assignments improved because they are too easy and unbalanced, (b) cultural knowledge is good $_{2}$ cultural communication part is enriched again, (c) pictures and illustrations are clarified, (d) improved governance to write a sentence, (e) correct diction which is rarely used in daily life or given a description of the meaning of the word, (f) the voice of the speaker is clarified, $(\mathrm{g})$ the material is made more presentable and continues to adjust the Indonesian teaching for foreign students standard and (h) an added glossary at the end of the page handbook. Inputs from experts enriched and became the basis for improving listening and verbal teaching materials filled with local Javanese culture.

Limited testing is the process of developing the next teaching material carried out at the ITFSI at UMP. The results obtained include (a) learners seem to understand the material that is integrated with the local culture of Central Java, (b) the classroom atmosphere is more cheerful because foreign students are active and enthusiastic about learning, (c) audio and video teaching materials greatly help foreign students understand above local cultural material and the use of sentences in everyday life, (d) foreign students can understand the cultural terms contained in the material learning because it is helped by images that support, (e) vocabulary increases, (f) foreign students want to actively ask, answer, and discuss according to the theme being studied, (g) knowledge and information on local culture increases, $(\mathrm{h})$ teachers feel helped because they no longer make teaching material as an introduction to culture, and (i) instructors find it easier to teach with the presence of this developed teaching material.

The next stage is a wider trial carried out at the ITFSI UNNES and ITFSI UNS. The learning syntaxes are (a) the teacher conveys the purpose of listening and speaking, (b) the learner reads the text of the discourse as an initial activity before entering listening and speaking material, (c) the teacher plays listening audio, (d) learners work on the question or the task is to test the understanding of material, and (e) learners watch video shows with local Javanese culture.

\subsection{Testing Stage}

The researcher conducted tests to answer two hypotheses, namely Ho = teaching materials for listening with local culture for foreign student does not improve the listening ability, and $\mathrm{Ha}=$ charged with local culture for students of BIPA learning in Central Java to improve their ability to speak and listen to BIPA learners. To examine the effectiveness of teaching materials developed for improving listening skills, researchers tested hypotheses using a onetrack t-test. The results of data analysis were seen from the results of Levene's test $p$ value. If 
the value of $p>0.05$, there is no difference between using teaching materials of BIPA educational institutions and the teaching materials developed.

\subsection{Reliability Test}

Reliability is used to show that an instrument is reliable enough to be used as a data collection tool because the instrument is good. Instrument reliability can be tested by analyzing the consistency of the items in the instrument with the test-retest technique). From 20 question items, number 20 can be used in the study because the validity can be seen from the correlation coefficient which is $0.404>0.30$. The minimum score is valid when $r=0.30$ (Masrun, 1979).

\subsection{Normality Test}

Tabel 1. Kolmogorov-Smiraov

\begin{tabular}{llll}
\hline No & Group & Sig. (2tail) & Conclusion \\
\hline 1 & Control Class & $0.463>0.05$ & Accepted/Normal \\
\hline 2 & Experiment Class & $0.121>0.05$ & Accepted/Normal \\
\hline
\end{tabular}

Both of classes are normal so the research can be continued using parametric statistics.

\subsection{Homogeneity Test}

Table 2. The Result of Homogeneity Test

\begin{tabular}{llllll}
\hline Variances & Levene Statistics & df1 & df2 & Sig. & Conclusion \\
\hline Experiment Class & .888 & 6 & 17 & .525 & Homogen \\
\hline
\end{tabular}

It can be seen that the pretest-posttest value difference data between the experimental group, control group 1 and control group 2 for listening ability had a Lavene statistic of 0.888 with a significance of $0.525>0.05$. $\mathrm{So}_{2}$ Ho can be accepted and stated that the intergroup data has a balanced variation.

Table 3. Differences in Post Ability of Listening Tests in Experimental Classes

\begin{tabular}{lllll}
\hline No & Note & Class A & Class B & Class C \\
\hline 1 & Average & 7 & 7 & 7.3 \\
\hline 2 & Highest Score & 7.5 & 7.5 & 8 \\
\hline 3 & Lowest Score & 6 & 6 & 6.5 \\
\hline
\end{tabular}

Every foreign student increased the score of listening skills in the experimental class. The average value of listening increased in the ITFSI class A of $8.7 \%$, in the ITFSI class $\mathrm{B}$ of $8.1 \%$, and in the ITFSI class $\mathrm{C}$ of $5 \%$. The increase in the value of listening ability is quite significant and shows that the teaching materials of listening to Indonesian language with local culture for foreign students in Central Java can be used by teachers and foreign students. When compared to the control class, the use of teaching material in the ITFSI class A increased by $3.1 \%$ and the difference was $5.6 \%$ from the experimental class. The ability to listen to the ITFSI control class B that uses the book Keren increased $2.5 \%$ and the difference of $5.6 \%$ compared to the experimental class. Meanwhile, the ability to listen to the ITFSI control class $\mathrm{C}$ using the Pijar book increased $3 \%$ and has a difference of $2 \%$ in terms of value.

The things that distinguish this teaching material from the available materials are: (1) developed according to the needs of teachers and foreign students; (2) the materials consider the content of the local culture of Central Java represented by three regions, namely 
Banyumas, Surakarta, and Semarang; (3) the materials consist of teaching handbooks, learning handbooks, listening audio, and video conversations containing local culture to support foreign students' understanding; and (4) the syllabus that has been discussed and adjusted to the current conditions so that it is contextual. There are 12 units in this teaching material and each has its own unique local culture.

Evaluation tools are made in the form of various listening assignments. After the teaching material becomes a prototype, the next process is editing. Manuscript editing is carried out by re-reading the text of the book, correcting writing errors and linguistics. Audio editing and videos of local culture require listening and watching, recording dialect errors, dialogues, or disturbing voices. The researcher corrected the text of the book, audio, and video until it was feasible to use.

Limited testing is the process of developing the next teaching materials carried out at the ITFSI at UMP. The results obtained include (a) foreign students seem to understand the material that is integrated with the local culture of Central Java; (b) the classroom atmosphere is more lively because foreign students are active and enthusiastic about learning; (c) audio and video teaching materials greatly help foreign students understand the local cultural materials and use of sentences in everyday life, (d) foreign students can understand the cultural terms by some pictures, (f) vocabulary increases, (g) foreign students want to actively ask, answer, and discuss according to the theme being studied, (h) knowledge and information on local culture increases, (i) teachers feel helped because they no longer make teaching material as an introduction to culture, and (j) instructors find it easier to teach with the presence of this developed teaching material.

The two instructors at the ITFSI tested this teaching material by teaching three different material units in the instructor's handbook and the learner's handbook. The results of the broader trials in both of these classes show the strengths of the teaching materials developed among others (a) making it easy for teachers, (b) foreign students felt comfortable because they were not burdened with material that is full of cultural terms, (c) the atmosphere of learning is more conducive, (d) foreign students feel confident communicating because they understood the vocabulary with local culture, and (e) foreign students were to carry out activities that support active communication with other learners and people. The development of listening skill is also important because it has a key role on language education, as well as it forms a basis for other language devices [14].

Listening learning can improve the ability of metacognitive awareness. Learners who conduct pair discussions and reflections will benefit when listening, more confident, learning various strategies to understand speech, more focus and seriousness, and not translating words per word. This condition can be carried out when the assessment tool listens accurately [15], teachers use effective techniques and consistently apply authentic listening media [16], and learners often listen at least twice in each activity[17][18][19].

\section{CONCLUSION}

This developed teaching material is able to improve the students' ability to listen. Efforts to provide solutions to the problems faced by foreign students and teachers include developing teaching materials in the form of learning handbooks, teaching handbooks, listening audio, and video dialogues filled with local culture. The reason why you should develop teaching materials is listening and talking are communication skills dependent on the ability to listen and speak. Both aspects of this language are developed with local culture because so far foreign students have difficulty using cultural terms in their daily lives. This teaching material 
can be more developed by other researchers and implemented by Indonesian teachers for foreign students especially standardized by legal institutions so it will be more useful.

\section{REFERENCE}

[1] Kawuryan, SekarPurbarini. Utilization of Cultural Objects as Learning Media Themes "Area Where I Live" in the Fourth Grade Elementary School: A Study of The Implementation of Integrative Thematic Approach". $2^{\text {nd }}$ International Seminar on Quality and Affordable Education (ISQAE 2013).2013.

[2] Roikhwanput, Mungmachon.Knowledge and Local Wisdom: Community Treasure. International Journal of Humanitie and Social Science. Thailand; UbonRatchathani University.2012.

[3] Tanriverdi, Belgin. Culture and Language Teaching Through Media. IL: National Textbook Company, Lincolnwood. 2008.

[4] Nurlina, L.,\& Israhayu, E.S. BIPA Learning Material Development for Empowering Thailand Students' Writing Competence. (pp. 57-66).Educare- JurnalKependidikan ,7(1).2014.

[5] Ampa, Andi Tenri. The Development of Contextual Learning Materials for the English Speaking Skills. (pp. 171 - 178). International Journal of Education and Research. Vol1. September 2013.2013.

[6] Andayani. The Correlation of Learning Motivation and Reasoning Ability to Scientific Writing Skills of Students in Teaching Indonesian to Speakers of Other Languages (TISOL). International Journal of Science and Research (IJSR). Vol 4. Diterbitkan 7 July 2015.Hal $1106-1110.2015$.

[7] Haghighi, Sara.Evaluation of "First Certificate Gold Course Book" : Evidence from Students of a Private English Institute in Iran. (pp. 149 - 164). International Journal of Instruction, 7(2).2014.

[8] Richards,J.C\&Rogers,TS. Approaches and Methods in Language Teaching. Cambridge: Cambridge University Press.2002.

[9] Talakina, Ekaterina V.Audiobook in Advanced ESL Classroom: Developing Critical Listening. International Conference "ICT for Language”.2006.

[10] Wahyuni,T.,Suwandi,S., Slamet,St.Y.,\&Andayani. Contextual Approach to the Development of an Indonesian Syntax Textbook in Higher Education in Indonesia. (pp. 211-226). International Journal of Instruction, 11(1).2018.

[11] Kramsch, Claire. The Relationship of Language and Culture. New York: Oxford University Press.2008.

[12] Dick, W, Carey,L \& Carey,J. The Systemic Design of Instruction $8^{\text {th }}$. Ed. Boston. MA: Pearson.2009.

[13] Hermayati. Relevansi Materi Pembelajaran Bahasa Asing dengan Pelestarian Budaya dan Pengembangan Pariwisata Kota Yogyakarta. Jurnal Penelitian BAPPEDA Kota Yogyakarta No.2. Desember 2007. Halaman 36-39. 2007.

[14]Acat, Bahaddin. M., Demiral,Hilmi.,Kaya,Mehmet Fatih. Measuring listening comprehension skills of $5^{\text {th }}$ grade school students with the help of web based system. 9(1).(pp. 211-224). DOI:10.12973/iji.2016.9116a.2016.

[15] La Clare, et.al..Assessing the Influence of Test Language on a Test of Listening Comprehension. Issued on International Journal of Innovation in English Language Teaching and Research. Volume 3. Nomor 2. Hal $179-200.2014$ 
[16]Zeng, Yazun. Investigating the Effect of Metacognitive Instruction on Chinese EFL Learner's Listening Performance.(pp. 139-158). International Journal of Innovation in English Language Teaching and Research. 3(2).2014.

[17] Paramasivan, S. Materials Development for Speaking Skills in Aviation English for Malaysian Air Traffic Controllers: Theory and Practice. (pp. 97-122). The Journal of Teaching English for Specific and Academic Purposes, 1 (2).2013.

[18] K. Saddhono, "Cultural and social change of foreign students in Indonesia: The influence of Javanese Culture in Teaching Indonesian to Speakers of Other Languages (TISOL)." IOP Conf. Ser.: Ear. and Envi. Sci.. vol. 126 no. 1 IOP Publishing, 2018.

[19] K. Saddhono, "Integrating Culture in Indonesian Language Learning for Foreign Speakers at Indonesian Universities." J. of Lang. and Lit. vol. 6 no.2 pp. 349-353, 2015 